\title{
Front Matter: Volume 9890
}

, "Front Matter: Volume 9890," Proc. SPIE 9890, Optical Micro- and Nanometrology VI, 989001 (17 May 2016); doi: 10.1117/12.2243899

SPIE. Event: SPIE Photonics Europe, 2016, Brussels, Belgium 


\title{
PROCEEDINGS OF SPIE
}

\section{Optical Micro- and Nanometrology VI}

\author{
Christophe Gorecki \\ Anand Krishna Asundi \\ Wolfgang Osten \\ Editors
}

\section{5-7 April 2016 \\ Brussels, Belgium}

Sponsored by

SPIE

Cosponsored by

B-PHOT-Brussels Photonics Team (Belgium)

Research Foundation Flanders (Belgium)

Visit Brussels (Belgium)

Cooperating Organisations

Photonics 21 (Germany)

EOS-European Optical Society (Germany)

KTN-the Knowledge Transfer Network (United Kingdom)

Graphene Flagship (Belgium)

Photonics Public Private Partnership (Belgium)

Published by

SPIE 
The papers in this volume were part of the technical conference cited on the cover and title page. Papers were selected and subject to review by the editors and conference program committee. Some conference presentations may not be available for publication. Additional papers and presentation recordings may be available online in the SPIE Digital Library at SPIEDigitallibrary.org.

The papers reflect the work and thoughts of the authors and are published herein as submitted. The publisher is not responsible for the validity of the information or for any outcomes resulting from reliance thereon.

Please use the following format to cite material from these proceedings:

Author(s), "Title of Paper," in Optical Micro- and Nanometrology Vl, edited by Christophe Gorecki, Anand Krishna Asundi, Wolfgang Osten, Proceedings of SPIE Vol. 9890 (SPIE, Bellingham, WA, 2016) Six-digit Article CID Number.

ISSN: 0277-786X

ISSN: 1996-756X (electronic)

ISBN: 9781510601352

Published by

SPIE

P.O. Box 10, Bellingham, Washington 98227-0010 USA

Telephone +1 3606763290 (Pacific Time) · Fax +1 3606471445

SPIE.org

Copyright @ 2016 , Society of Photo-Optical Instrumentation Engineers.

Copying of material in this book for internal or personal use, or for the internal or personal use of specific clients, beyond the fair use provisions granted by the U.S. Copyright Law is authorized by SPIE subject to payment of copying fees. The Transactional Reporting Service base fee for this volume is $\$ 18.00$ per article (or portion thereof), which should be paid directly to the Copyright Clearance Center (CCC), 222 Rosewood Drive, Danvers, MA 01923. Payment may also be made electronically through CCC Online at copyright.com. Other copying for republication, resale, advertising or promotion, or any form of systematic or multiple reproduction of any material in this book is prohibited except with permission in writing from the publisher. The CCC fee code is 0277-786X/16/\$18.00.

Printed in the United States of America.

Publication of record for individual papers is online in the SPIE Digital Library.

\section{SPIE. DIGITAL}

Paper Numbering: Proceedings of SPIE follow an e-First publication model. A unique citation identifier (CID) number is assigned to each article at the time of publication. Utilization of CIDs allows articles to be fully citable as soon as they are published online, and connects the same identifier to all online and print versions of the publication. SPIE uses a six-digit CID article numbering system structured as follows:

- The first four digits correspond to the SPIE volume number.

- The last two digits indicate publication order within the volume using a Base 36 numbering system employing both numerals and letters. These two-number sets start with 00, 01, 02, 03, 04, $05,06,07,08,09,0 A, 0 B \ldots$ OZ, followed by 10-1Z, 20-2Z, etc. The CID Number appears on each page of the manuscript. 


\title{
Contents
}

\author{
vii Authors \\ ix Conference Committee
}

\section{SESSION 1 DIGITAL HOLOGRAPHY}

989002 Digital holographic microscopy for the characterization of microelectromechanical systems (Invited Paper) [9890-1]

989003 Photon counting digital holography [9890-2] not yet approved

989004 Partial spatial coherence illumination in digital holographic microscopy: quantitative analysis of the resulting noise reduction [9890-3]

989005 Perspectives of multimode fibers and digital holography for optogenetics [9890-4]

989006 Digital holography with electron wave: measuring into the nanoworld (Invited Paper) [9890-5]

989007 Measurement of hygroscopic strain in deodar wood during convective drying using lensless Fourier transform digial holography [9890-6]

\section{SESSION 2 3D METROLOGY}

989008 Structured light optical microscopy for three-dimensional reconstruction of technical surfaces [9890-7]

989009 Triangulation-based 3D surveying borescope [9890-8]

9890 OA High-contrast 3D image acquisition using HiLo microscopy with an electrically tunable lens [9890-9]

$9890 \mathrm{OB}$ Three-dimensional measurements with a novel technique combination of confocal and focus variation with a simultaneous scan [9890-10]

\section{SESSION 3 OPTICAL TOMOGRAPHY}

9890 0C Array-type miniature interferometer as the core optical microsystem of an optical coherence tomography device for tissue inspection (Invited Paper) [9890-11]

9890 OD Vertical comb-drive microscanner with $4 \times 4$ array of micromirrors for phase-shifting Mirau microinterferometry [9890-12]

9890 OE High-resolution full-field optical coherence tomography using high dynamic range image processing [9890-14] 
9890 OF Space-domain, filtered backpropagation algorithm for tomographic configuration with scanning of illumination [9890-15]

\section{SESSION 4 NANOSCALE METROLOGY, NANOIMAGING, AND NEAR-FIELD MICROSCOPY}

$98900 \mathrm{O}$ Overview of label-free far field optical nanoscopy techniques for nanometrology [9890-16]

9890 ol A silicon superlens with a simple design working at visible wavelengths [9890-18]

$9890 \mathrm{0J}$ High-resolution photocurrent mapping of thin-film solar cells using scanning near-field optical microscopy [9890-19]

9890 OK Optical properties of spray coated layers with carbon nanotubes and graphene nanoplatelets [9890-20]

\section{SESSION 5 SCATTEROMETRY}

$9890 \mathrm{OL}$ Wavefront shaping for flow-field measurements through varying phase boundaries [9890-21]

$98900 \mathrm{M}$ Robust determination of asymmetric side wall angles by means of coherent scanning Fourier scatterometry [9890-22]

$9890 \mathrm{ON}$ Structure and mesoscopic characterization of laser ablated carbon nanoparticles in water by Raman scattering [9890-23]

989000 Speckle decorrelation study of phase heterogeneous liquid medium [9890-24]

9890 OP Inverse scattering spectroscopic method for the fast measurement of the number and mass concentrations of metal nanoparticle colloid [9890-25]

\section{SESSION 6 TOPOGRAPHY AND SURFACE MEASUREMENTS}

$98900 Q$ Local reflectance spectra measurements of surfaces using coherence scanning interferometry [9890-27]

9890 OR Two-dimensional low-coherence interferometry for the characterization of nanometer wafer topographies [9890-28] not yet approved

9890 OS Sensing roughness and polish direction [9890-29]

\section{SESSION 7 SPECIALIZED TECHNIQUES}

9890 OT Production of arbitrary polarized light beams with a liquid crystal spatial modulator (Invited Paper) [9890-30] 
$9890 \mathrm{OV}$ Evaluation of single-shot and two-shot fringe pattern phase demodulation algorithms aided by the Hilbert-Huang transform [9890-32]

9890 OW Effective generation of unidirectional SPP beam with arbitrary profile [9890-33]

\section{SESSION 8 INTERFEROMETRY APPLICATIONS}

$98900 \mathrm{X}$ Influences of edges and steep slopes in 3D interference and confocal microscopy [9890-34]

\section{POSTER SESSION}

989011 Vertical integration of array-type miniature interferometers at wafer level by using multistack anodic bonding [9890-13]

989012 Measurement of defects by measuring of light scattering from surfaces using focused illumination [9890-38]

989013 Precision topographic inspection of MOEMS by moiré interferometry [9890-39]

989014 Optical characterization of $\mathrm{SiO}_{2}$ thin films using universal dispersion model over wide spectral range [9890-40]

989015 3D through silicon via profile metrology based on spectroscopic reflectometry for SOI applications [9890-41]

989016 Application of laser radiation for investigation of oriented polypropylene membranes [9890-42]

989018 Subaperture method for aspheric surface metrology using curvature data [9890-44]

9890 lA Aberration retrieval for the characterization of micro-optical components [9890-46]

9890 1B Capillary-scale interferometry at high angles of scattering for refractive index measurements of small volumes [9890-47]

9890 ID Optical properties of polymer microtips investigated with workshop tomographic system [9890-49] 
Proc. of SPIE Vol. $9890989001-6$

Downloaded From: https://www.spiedigitallibrary.org/conference-proceedings-of-spie on 26 Apr 2023 Terms of Use: https://www.spiedigitallibrary.org/terms-of-use 


\section{Authors}

Numbers in the index correspond to the last two digits of the six-digit citation identifier (CID) article numbering system used in Proceedings of SPIE. The first four digits reflect the volume number. Base 36 numbering is employed for the last two digits and indicates the order of articles within the volume. Numbers start with 00, 01, 02, 03, 04, 05, 06, 07, 08, 09, OA, OB...0Z, followed by 10-1Z, 20-2Z, etc.

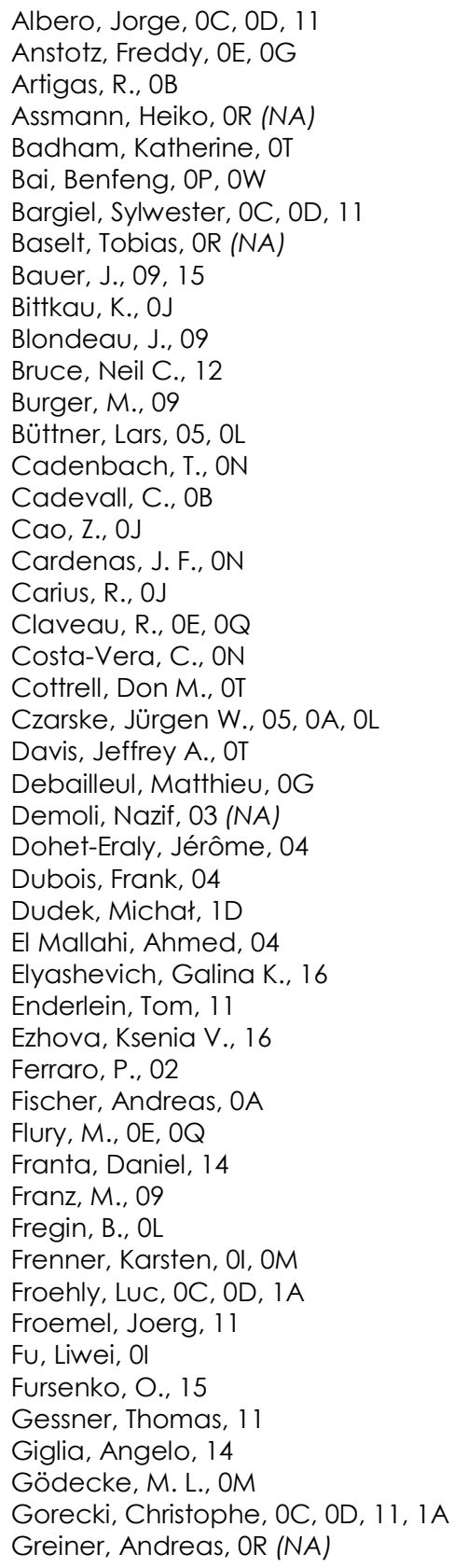

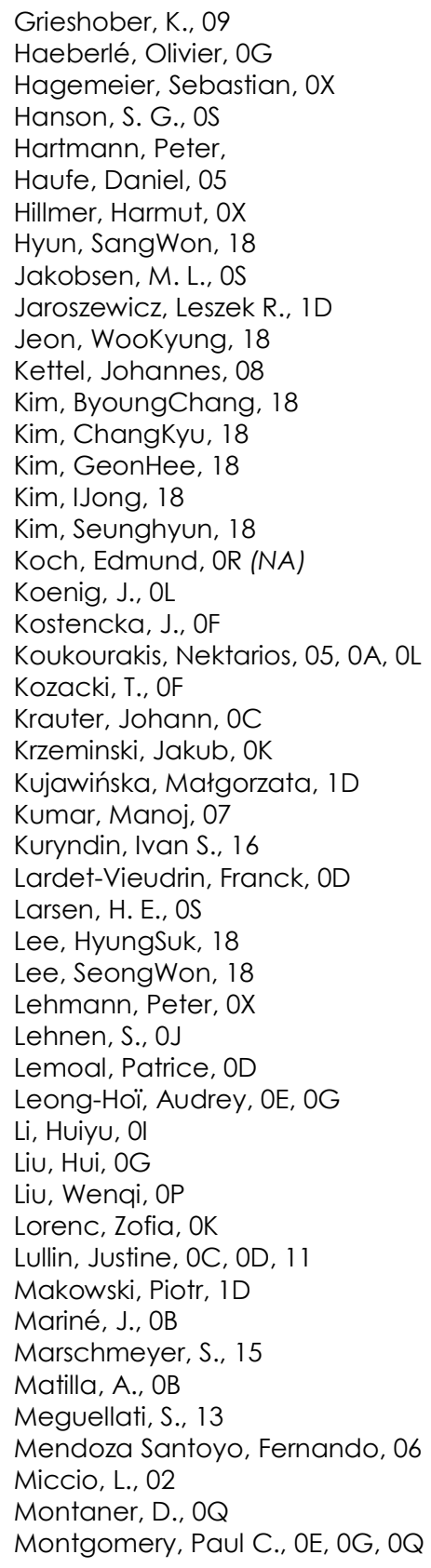


Moreno, Ignacio, OT

Mouti, S., 09

Müller, Claas, 08

Nečas, David, 14

Nelsen, Bryan L., OR (NA)

Ohlídal, Ivan, 14

Olesen, A. S., OS

Osten, Wolfgang, OC, OI, OM

Pagliarulo, V., 02

Parat, Vincent, 1D

Park, Tae Jin, 18

Passilly, Nicolas, OC, 0D, 11, 1A

Patorski, Krzysztof, OV

Pavicic, Mladen, 03 (NA)

Paz, J. L., ON

Pedersen, H. C., OS

Pedersen, T. F., OS

Pérez, J., OB

Perrin, Stéphane, OC, OD, IA

Peterhänsel, S., OM

Philipp, Katrin, OA

Pobiedina, Valentyna, 00

Pulwer, S., 09

Rautenberg, J., 09

Reinecke, Holger, 08

Rodríguez-Núñez, O., 12

Salbut, Leszek, OK

Sánchez-López, Maria M., OT

Schrader, S., 09

Serio, B., OE

Shakher, Chandra, 07

Simon, Bertrand, $0 G$

Skenderović, Hrvoje, 03 (NA)

Sluzewski, Lukasz, OV

Smolarski, André, OA

Steglich, P., 09

Stipčević, Mario, 03 (NA)

Stubager, J., OS

Stürmer, Moritz, OA

Sunderland, Zofia, OV

Świrniak, Grzegorz, 1B

Taudt, Christopher, OR (NA)

Trusiak, Maciej, OV

Uhring, W., OE

Villringer, C., 09

Voelkl, Edgar, 06

Wallrabe, Ulricke, $0 \mathrm{~A}$

Wang, Qixia, OW

Wang, Wei-Shan, 0C, 11

Wiemer, Maik, OC, 11

Wirth, F., 09

Woidt, Carsten, OX

Wroblewski, Grzegorz, OK

Wu, Xiaochun, OP

Wu, Xiaoyu, OW

Xie, Weichang, OX

Yakunov, Andrey, 00

Yang, Guoce, OP

You, Oubo, OW
Yourassowsky, Catherine, 04

Zhang, S.-L., ON

Zhang, Z.-B., ON

Zhu, Zhendong, OW

Zinchik, Alexander A., 16 


\section{Conference Committee}

Symposium Chairs

Francis Berghmans, Vrije Universiteit Brussel (Belgium)

Jürgen Popp, Institut für Photonische Technologien e.V.

(Germany)

Ronan Burgess, European Commission Photonics Unit (Belgium)

Peter Hartmann, SCHOTT AG (Germany)

Honorary Symposium Chair

Hugo Thienpont, Vrije Universiteit Brussel (Belgium)

Conference Chairs

Christophe Gorecki, FEMTO-ST (France)

Anand Krishna Asundi, Nanyang Technological University (Singapore)

Wolfgang Osten, Institut für Technische Optik (Germany)

Conference Program Committee

Jürgen W. Czarske, Technische Universität Dresden (Germany)

Peter J. de Groot, Zygo Corporation (United States)

Konstantinos Falaggis, Warsaw University of Technology (Poland)

Pietro Ferraro, Istituto Nazionale di Ottica (Italy)

Cosme Furlong, Worcester Polytechnic Institute (United States)

Yoshio Hayasaki, Utsunomiya University (Japan)

Peter H. Lehmann, Universität Kassel (Germany)

Andreas Ostendorf, Ruhr-Universität Bochum (Germany)

Yukitoshi Otani, Utsunomiya University (Japan)

Heidi Ottevaere, Vrije Universiteit Brussel (Belgium)

Nicolas Passilly, FEMTO-ST (France)

Christof Pruss, Universität Stuttgart (Germany)

Xiaocong Yuan, Nankai University (China)

Huimin Xie, Tsinghua University (China)

\section{Session Chairs}

1 Digital Holography

Wolfgang Osten, Universität Stuttgart (Germany)

2 3D Metrology

Jürgen W. Czarske, Technische Universität Dresden (Germany) 
3 Optical Tomography

Christophe Gorecki, FEMTO-ST (France)

4 Nanoscale Metrology, Nanoimaging, and Near-field Microscopy

Heidi Ottevaere, Vrije Universteit Brussels (Belgium)

5 Scatterometry

Fernando Mendoz-Santoyo, Centro de Investigaciones en Óptica,

A.C. (Mexico)

6 Topography and Surface Measurements

Nazif Demoli, Institut za Fiziku(Croatia)

7 Specialized Techniques

Nicolas Passilly, FEMTO-ST (France)

8 Interferometry Applications

Anand Krishna Asundi, Nanyang Technological University (Singapore) 